\title{
THE EFFECT OF SOLID MANURE INCORPORATION INTO THE SOIL ON THE EMISSION OF GASES AND ODOURS
}

Paulina MIELCAREK, Institute of Technology and Life Sciences, Department of the Technology and Emissions Development in Farms, Address: Biskupińska 67, 60-463 Poznań, Poland; e-mail: p.mielcarek@itp.edu.pl (corresponding author)

Wojciech RZEŹNIK, Institute of Technology and Life Sciences, Department of the Technology and Emissions Development in Farms, Address: Biskupińska 67, 60-463 Poznań, Poland; e-mail: w.rzeznik@itp.edu.pl

Zbyszek ZBYTEK, Industrial Institute of Agricultural Engineering, Testing Laboratory for Agricultural Machines, Address: Starołęcka 31, 60-963 Poznań, Poland; e-mail: zbytek@ pimr.poznan.pl

The aim of the study was to determine the level of emission reduction of selected harmful gases and odours following immediate manure incorporation into soil, using the prototype manure applicator. The research was carried out at the Experimental Station of the National Research Institute of Animal Production, in September 2016. Two experimental fields size 6 x 100 m were located on corn stubble in the distance of $40 \mathrm{~m}$. In field A, the solid manure was incorporated into the soil using the prototype manure applicator. In field B, manure application was made by manure spreader. The prototype manure applicator was designed and made by Industrial Institute of Agricultural Engineering. The concentration of harmful gases $\left(\mathrm{NH}_{3}, \mathrm{CO}_{2}, \mathrm{CH}_{4}, \mathrm{~N}_{2} \mathrm{O}\right)$ and odours was measured during the study. Measurements were made in the following periods: immediately after application and 2, 4, 6, 10 and 14 hours after application. The concentration of studied gases was measured immediately after sampling by the photoacoustic spectrometer (Multi Gas Monitor Innova 1312). The odours concentration was determined within 30 hours after air sampling by dynamic olfactometry using the TO 8 olfactometer. The solid manure incorporation reduced $\mathrm{NH}_{3}$ emissions by an average of $66 \%$. For the other studied gases the differences in concentration were too small or this concentration was similar to concentration of these gases in surrounding air. The incorporation of solid manure limited also odour emissions. The level reduction decreased with time and amounted to an average of $25 \%$.

Keywords: solid manure, fertilization, odour emission, ammonia emission

\section{INTRODUCTION}

Emission of harmful gases to the atmosphere: ammonia $\left(\mathrm{NH}_{3}\right)$ and greenhouse gases (methane- $\mathrm{CH}_{4}$, nitrous oxide$\mathrm{N}_{2} \mathrm{O}$, carbon dioxide- $\mathrm{CO}_{2}$ ) from agricultural sources is currently the major problem both in terms of environmental and economic. One of the main sources of emissions is the manure management. During storage, natural fertilizers may release about 20-50\% of contained nitrogen as ammonia (Chadwick, 2005; Marcinkowski, 2000). Moreover, while application on agricultural land, natural fertilizers may lose next 25 to $95 \%$ of nitrogen (Sapek, 2005). It is estimated that total nitrogen emission in the form of ammonia during the manure management is about 80\% (Pietrzak, 2006). Emissions of methane from manure management is about 12\%, and nitrous oxide is about 14\% (Olecka et al., 2017). The release of these gases into the atmosphere negatively affects the environment. Ammonia causes acidification and eutrophication of natural ecosystems. Methane and nitrous oxide contribute to the greenhouse effect, and additionally nitrous oxide causes the ozone layer depletion (Dämmgen and Erisman, 2005; Schils et al., 2007).

According to the Announcement of the Minister of Agriculture and Rural Development of 17 February 2014 on the publication of the consolidated text of the Regulation of the Minister of Agriculture and Rural Development on the detailed method of application of fertilizers and training in their use, natural fertilizers should be applied over the all field and it should be covered or mixed with soil no later than the day following their application (Announcement..., 2014). Manure, which is not quickly incorporated into the soil, lose nitrogen by ammonia emission to the atmosphere and surface runoff. Therefore the soil gets less nutrient elements used by plants during their growth. Additionally, manure left on the field is a source of unpleasant odours (Kleinman et al., 2002; Maguire et al., 2011).

Manure spreaders, with vertical or horizontal shredding and scattering beaters, are commonly used for application of manure in fields. Generally, these devices spread the manure in a very wide area, what limit possibility of using them in cooperation with other tools, as modular construction. The commonly used machines spread the manure with such a force, that it usually falls down on the cultivator or behind it. Therefore, the second tractor with a cultivation tool is necessary to incorporate the manure into the soil.

Copyright (C) 2017 The Authors. Published by Aleksandras Stulginskis University. This is an open-access article distributed under the terms of the Creative Commons Attribution License (CC-BY 4.0), which permits unrestricted use, distribution, and reproduction in any medium, provided the original author and source are credited. 
The aim of the study was to determine the level of emission reduction of selected harmful gases and odours following immediate manure incorporation into soil, using the prototype manure applicator.

\section{MATERIALS AND METHODS}

The research was carried out at the Experimental Station of the National Research Institute of Animal Production, in the Kostkowice Farm, in September 2016. Two experimental fields size 6 x 100 m were located on corn stubble in the distance of $40 \mathrm{~m}$. In field $\mathrm{A}$, the solid manure was incorporated into the soil using the prototype manure applicator. In field B, manure application was made by manure spreader (Fig. 1). The prototype manure applicator was designed and made by Industrial Institute of Agricultural Engineering, as part of the BIOGAS \& EE project (Fig. 2). This applicator in a single working pass spreads manure and then incorporates it into the soil. During one operation the manure is transported, spread and incorporated (Talarczyk et al., 2016; Strategic program...).

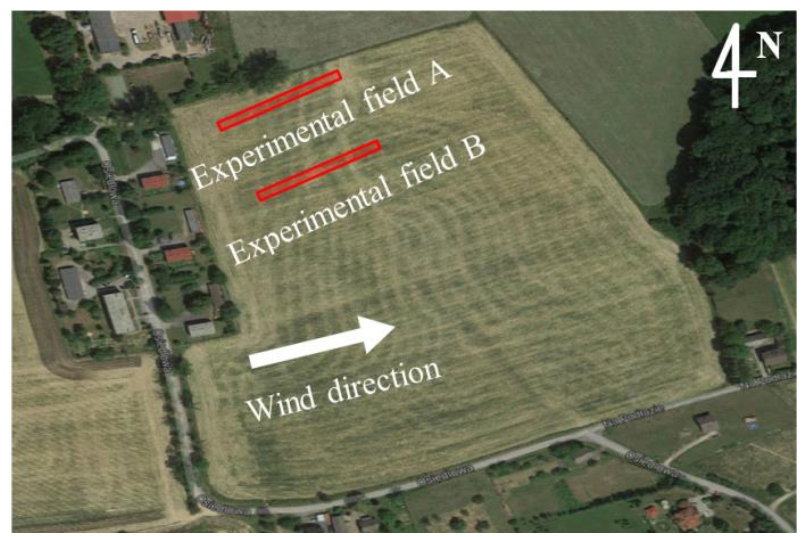

Figure 1. Location of experimental fields

During the study the concentrations of selected gases: ammonia $\left(\mathrm{NH}_{3}\right)$, carbon dioxide $\left(\mathrm{CO}_{2}\right)$, methane $\left(\mathrm{CH}_{4}\right)$ and nitrous oxide $\left(\mathrm{N}_{2} \mathrm{O}\right)$ were measured and odour concentration was determined. The concentration of studied gases was measured by the photoacoustic spectrometer (Multi Gas Monitor Innova 1312), immediately after sampling. The detection limit of the studied gases was: $0.06 \mathrm{mg} \cdot \mathrm{m}^{-3}(0.03 \mathrm{ppm})$ for $\mathrm{N}_{2} \mathrm{O}, 0.28 \mathrm{mg} \cdot \mathrm{m}^{-3}(0.4 \mathrm{ppm})$ for $\mathrm{CH}_{4}, 9.89 \mathrm{mg} \cdot \mathrm{m}^{-3}(5.1 \mathrm{ppm})$ for $\mathrm{CO}_{2}$ and $0.15 \mathrm{mg} \cdot \mathrm{m}^{-3}(0.2 \mathrm{ppm})$ for $\mathrm{NH}_{3}$. Before manure application, the concentrations of these gases were measured in surrounding air (background).

The odours concentration was measured within 30 hours after air sampling. The tests were made in Laboratory of Agricultural Technology and Biosystems of the Institute of Technology and Life Sciences in Poznań. The odours concentration was determined by dynamic olfactometry according to PN-EN 13725:2007 standard, using the TO 8 olfactometer. Evaluation of odours concentration was conducted by a team of four experts.

Measurements were made in the following periods: immediately after application and 2, 4, 6, 10 and 14 hours after application. The concentrations of the studied pollutants were measured in the air sampled at a height of $0.4 \mathrm{~m}$ above the experimental fields. Before sampling, the selected parts of experimental fields were covered with special chambers for the sampling air from surface sources (Fig. 3).

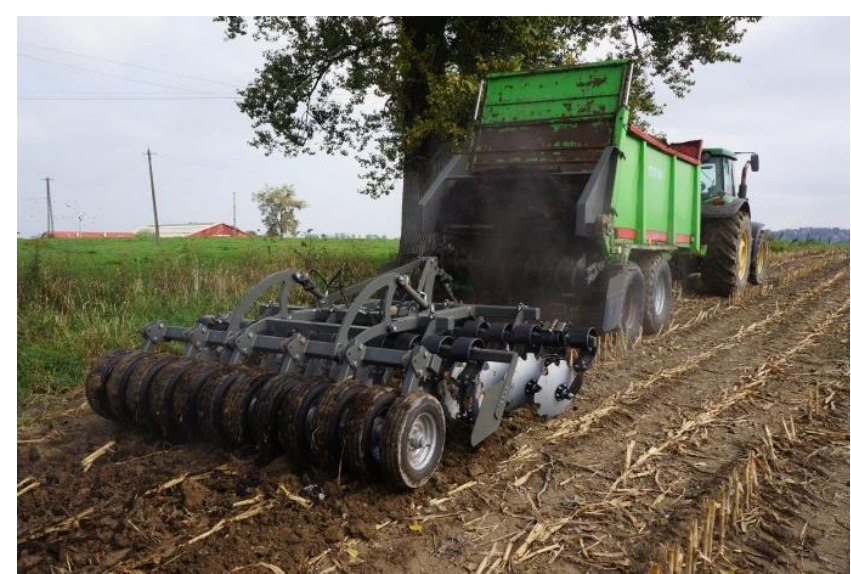

Figure 2. Prototype manure applicator

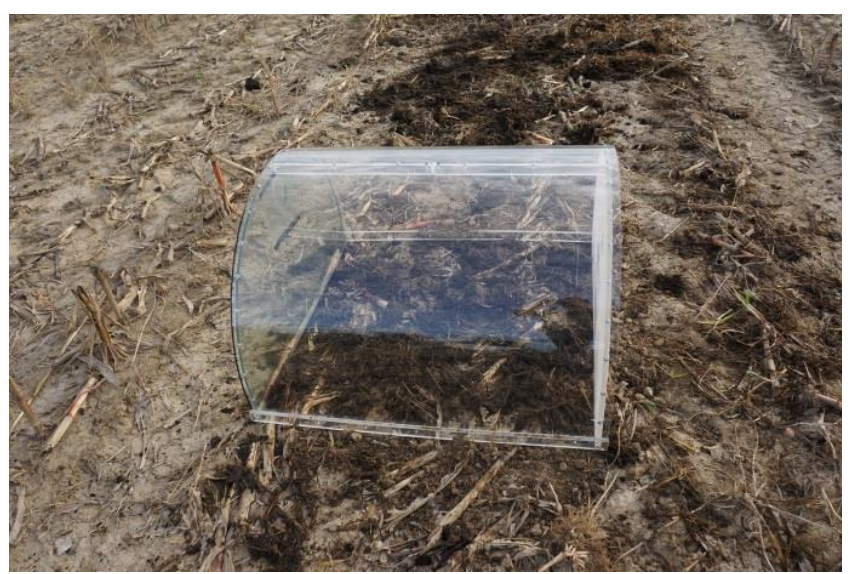

Figure 3. Research chamber

The time of a single air sampling was 5 minutes. The CSD30 sampler from Ecoma and 8-liter disposable bags made of Nalophan (PET) were used for sampling. It was assumed that the stream of air $(V R)$ between following 
measurements was the same for both experimental fields. Based on the measured concentrations of the studied gases and odours, the concentration distribution of the pollutants in the air was estimated for the study period. The equation of concentration in time $f(t)$ was calculated using the regression analysis, which also represented the changes in air pollutant emission, because the stream of air was the same. The total emissions $\left(E_{t o t}\right)$ during the measurements were calculated using equation (1):

$$
E_{t o t}=V R \int_{0}^{14} f(t) d t
$$

where:

$$
\begin{aligned}
& V R \text { - ventilation rate } \\
& t \text { - time } \\
& f(t) \text { - regression equation }
\end{aligned}
$$

The level of reduction of studied gases and odours resulting from immediate manure incorporation into the soil was determined on the basis of total emissions.

\section{RESULTS AND DISCUSION}

The mean values of concentrations of studied gases measured at defined intervals of time after the application of cow manure are presented in table 1 . It includes also the concentrations of $\mathrm{NH}_{3}, \mathrm{~N}_{2} \mathrm{O}, \mathrm{CH}_{4}$ and $\mathrm{CO}_{2}$ in the surrounding air before manure application (background). Statistically significant differences $(\mathrm{p} \leq 0.05)$ in gas concentrations between fields were noted for $\mathrm{NH}_{3}$ and $\mathrm{CO}_{2}$. For all study, the concentrations of these gases in the field, where the manure was immediately incorporated into the soil were less than on the other field. The concentration of $\mathrm{NH}_{3}$ and $\mathrm{CO}_{2}$ in the experimental fields decreased in time and it reached value similar to this noted in the background after 14 and 10 hours,

\begin{tabular}{|c|c|c|c|c|c|c|c|c|}
\hline \multirow{4}{*}{$\begin{array}{l}\text { Time } \\
\text { (h) }\end{array}$} & \multicolumn{8}{|c|}{ Gas concentration $\left(\mathrm{mg} \cdot \mathrm{m}^{-3}\right)$} \\
\hline & \multirow{2}{*}{\multicolumn{2}{|c|}{$\frac{\mathrm{NH}_{3}}{\text { Background }-0.21}$}} & \multirow{2}{*}{\multicolumn{2}{|c|}{$\frac{\mathrm{N}_{2} \mathrm{O}}{\text { Background }-0.81}$}} & \multicolumn{2}{|c|}{$\mathrm{CH}_{4}$} & \multicolumn{2}{|c|}{$\mathrm{CO}_{2}$} \\
\hline & & & & & Backg & -0.24 & Backgro & -828.26 \\
\hline & Field A & Field B & Field A & Field B & Field A & Field B & Field A & Field B \\
\hline 0 & 2.33 & 18.29 & 0.83 & 0.79 & 0.66 & 1.27 & 1080.90 & 1146.76 \\
\hline 2 & 2.29 & 6.71 & 0.73 & 0.98 & 0.61 & 0.04 & 934.38 & 953.73 \\
\hline 4 & 1.57 & 4.14 & 0.71 & 0.88 & 0.19 & 0.04 & 905.72 & 987.36 \\
\hline 6 & 0.74 & 1.12 & 0.73 & 0.67 & 0.36 & 0.09 & 853.31 & 869.49 \\
\hline 10 & 0.43 & 0.39 & 0.71 & 0.67 & 0.62 & 0.47 & 828.80 & 834.14 \\
\hline 14 & 0.27 & 0.24 & 0.72 & 0.66 & 0.24 & 0.06 & 804.29 & 811.07 \\
\hline
\end{tabular}
respectively. For $\mathrm{N}_{2} \mathrm{O}$ and $\mathrm{CH}_{4}$, measured concentrations were comparable to background and unclear variability in time did not allow to determine the effect of manure incorporation on the emission.

Table 1. Mean concentration values of studied gases (Bartkowiak et al., 2017)

Field A - prototype manure applicator; Field B - manure spreader

The difference in $\mathrm{NH}_{3}$ concentration between the experimental fields decreased over time from $87 \%$ (immediately after application) to $34 \%$ (6 hours after application). For $\mathrm{CO}_{2}$, there were statistically significant differences in concentrations between the fields in each study period, but the reduction effect was not as high as for $\mathrm{NH}_{3}$ and ranged from 0.6 to $8.3 \%$. Despite the differences, their values were too small and dependent on other factors (soil moving), so the effect of immediate manure incorporation on $\mathrm{CO}_{2}$ emissions cannot be determined.

Figures 4 and 5 show the changes of mean ammonia concentrations in time, for both experimental fields.

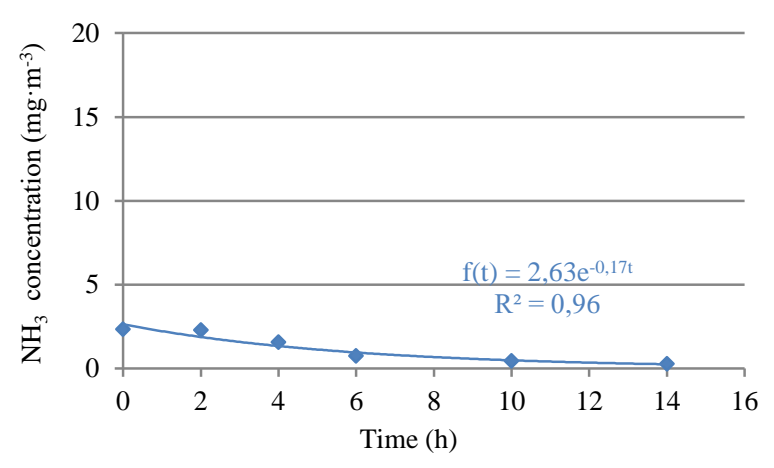

Figure 4. $\mathrm{NH}_{3}$ concentration in field $\mathrm{A}$

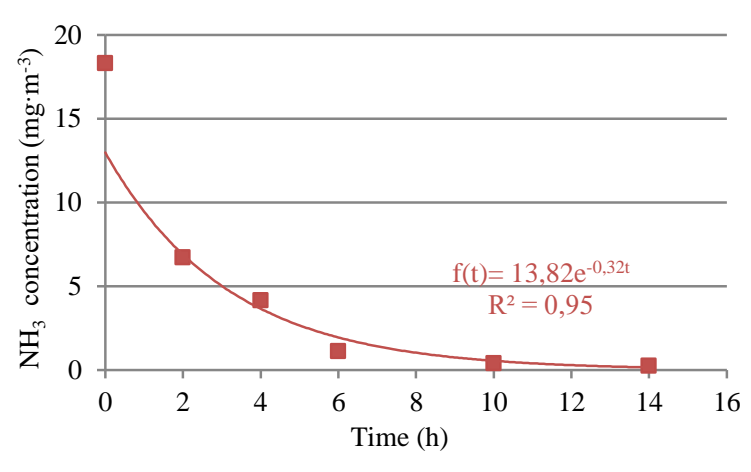

Figure 5. $\mathrm{NH}_{3}$ concentration in field $\mathrm{B}$

The mean level of $\mathrm{NH}_{3}$ reduction resulting from immediate manure incorporation, based on total emissions calculated from equation (1), was $66 \%$. Similar results have been reported in earlier studies, but the manure incorporation 
in those studies was done using a second tractor with a plough, disc harrow or cultivator. Webb et al. (2004) found that the immediate incorporation of pig manure reduced $\mathrm{NH}_{3}$ emissions by an average of $92 \%$. In other experiment, Webb et al. (2014) investigated the effect of immediate incorporation of solid manures such as cow manure, pig manure and poultry manure using a mouldboard plough, disc or tine on two types of soils. They have shown that immediate incorporation by plough reduces $\mathrm{NH}_{3}$ emissions by $90 \%$ and by $60 \%$ by disc and tine. McGinn and Sommer (2007) measured a reduction in $\mathrm{NH}_{3}$ emissions of about $80 \%$ from immediate incorporation by a double-offset cultivator. Pote and Meisinger (2014) studied the effect of application and incorporation methods of poultry manure on $\mathrm{NH}_{3}$ emissions. Compared to conventional surface spreading of poultry manure, $\mathrm{NH}_{3}$ emission decreased an average of $67 \%$ when the manure application was followed by light disking, and it decreased an average of $88 \%$ when the manure was applied by using the prototype USDA ARS applicator.

The values of odour concentrations measured in experimental fields and their variability in time are presented in figures 6 and 7 (Bartkowiak et al., 2017). During the study, in the field, where the manure was immediate incorporated into soil, lower concentrations of odours were observed. The difference in the concentrations of odours between experimental fields decreased in time from $41 \%$ (immediately after application) to $4 \%$ (6 hours after application).

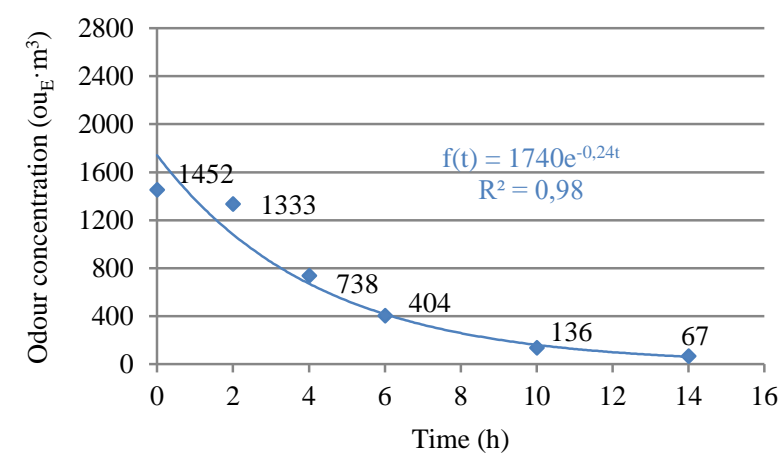

Figure 6. Odour concentration in field A

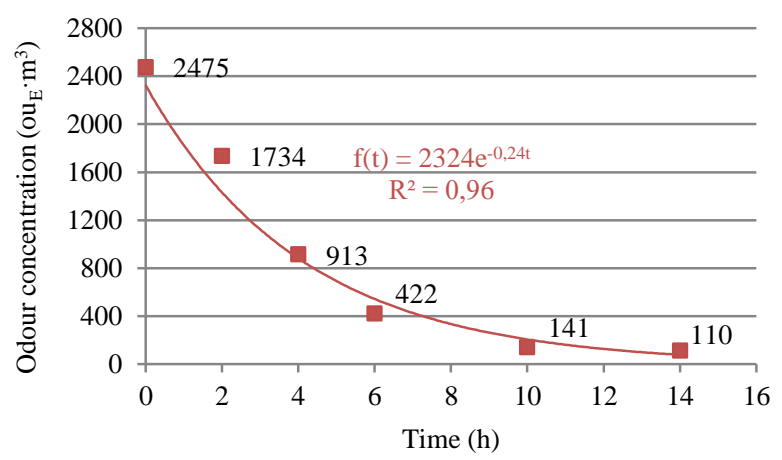

Figure 7. Odour concentration in field B

Based on calculations of total emission, in accordance with equation (1), the reduction in emission of odours associated with the immediate manure incorporation was determined, which is $25 \%$. Similar results were reported by Hanna et al. (2000), investigating the effect of six different techniques of pig manure application on odour emission. They observed that most of the tested techniques involving some soil incorporation reduced odour emissions by 20 to $90 \%$ compared to broadcast application. Additionally, the level of odour decreased quickly with time and often within a single day was statistically insignificant with the level of odour from untreated soil. Lau et al. (2003) found that the swine manure odour emission rate with subsurface application was reduced by 8 to $38 \%$ compared with conventional splashplate application. Pain et al. (1991) observed a reduction in odour emissions of $85 \%$ in the first hour after slurry ploughing immediately after application. The using of a rotary harrow reduced the odour emissions by $45 \%$.

Moreover, simultaneous application of manure and immediate incorporation into soil allows the execution of the two agricultural treatments in a single working pass, which reduces the operating time, the operation cost and reduces the negative influence of traction on the soil by the lower compaction and limited over-drying field surface.

\section{CONCLUSIONS}

Based on the research and obtained results the following conclusions can be drawn:

- The immediate manure incorporation into soil resulted in an average of $66 \%$ reduction of $\mathrm{NH}_{3}$ emissions from experimental fields. This reduction decreased in time from 87 to $34 \%$.

- For $\mathrm{CO}_{2}, \mathrm{~N}_{2} \mathrm{O}, \mathrm{CH}_{4}$ the differences in concentration were too small or this concentration was similar to concentration of these gases in surrounding air before manure application.

- The immediate manure incorporation into soil reduced odour emissions about $25 \%$. This reduction decreased in time and ranged from 41 to $4 \%$.

\section{REFERENCES}

1. Bartkowiak, A., Jadczyszyn, T., Mac, J., Matros, B., Matyka, M., Mielcarek, P., Rzeźnik, W., Stekla, J., Talarczyk, W., Zbytek, Z., Witorożec, A. 2017. Different aspects of the use of biogas digestat. (Ed.) Rzeźnik W. - in print. [in Polish]

2. Chadwick Chadwick, D.R. 2005. Emissions of ammonia, nitrous oxide and methane form cattle manure heaps effect of compaction and covering. Atmospheric Environment, Vol. 4, pp. 787-799. https://doi.org/10.1016/j.atmosenv.2004.10.012

3. Dämmgen, U., Erisman, J.W. 2005. Emission, transmission, deposition and environmental effects of ammonia from agricultural sources. In: Emissions from European agriculture. (Ed.) T. Kuczyński, U. Dämmgen, J. Webb, A. Myczko. Wageningen. Wageningen Academic Publishers, The Netherlands, Scientific Network AGRORISKS, Poland, pp. 97-112.

4. Hanna, H.M., Bundy D.S., Lorimor J.C., Mickelson S.K., Melvin S.W., Erbach D.C. 2000. Manure incorporation equipment effects on odor, residue cover, and crop yield. Applied Engineering in Agriculture, Vol. 16, pp. $621-627$. https://doi.org/10.13031/2013.5376 
5. Kleinman, P.J.A., Sharpley, A.N., Moyer, B.G., Elwinger, G.F. 2002. Effect of mineral and manure phosphorus sources on runoff phosphorus. Journal of Environmental Quality, Vol. 31, pp. 2026-2033. https://doi.org/10.2134/jeq2002.2026

6. Lau, A., Bittman S., Lemus G. 2003. Odor measurements from manure spreading using a subsurface deposition applicator. Journal of Environmental Science and Health, Part B, Vol. 38, pp. 233-240. https://doi.org/10.1081/PFC-120018452

7. Maguire, R.O., Kleinman, P.J.A., Dell, C.J., Beegle, D.B., Brandt, R.C., McGrath, J.M., Ketterings, Q.M. 2011. Manure Application Technology in Reduced Tillage and Forage Systems: A Review. Journal of Environmental Quality, Vol. 40, pp. 292-301. https://doi.org/10.2134/jeq2009.0228

8. Marcinkowski, T. 2000. Ammonia emissions from farm manure storages in the aspect of quantitative measurements. Zeszyty Naukowe AR Szczecin, Z. 84, pp. 269-274. [In Polish]

9. McGinn, S.M., Sommer, S.G. 2007. Ammonia emissions from land-applied beef cattle manure. Canadian Journal of Soil Science, Vol. 87, pp. 345-352. https://doi.org/10.4141/S06-053

10. Announcement of the Minister of Agriculture and Rural Development of 17 February 2014 on the publication of the consolidated text of the Regulation of the Minister of Agriculture and Rural Development on detailed application of fertilizers and training of their application. Dz.U. 2014 poz. 393. [In Polish]

11. Olecka, et al. 2017. Poland's National Inventory Report 2017. Greenhouse Gas Inventory for 1988-2015. Institute of Environmental Protection - National Research Institute, The National Centre for Emissions Management, Warsaw.

12. Pain, B.F., Clarkson C.R., Phillips V.R., Klarenbeek J.V., Misselbrook T.H., Bruins M. 1991. Odour emission arising from application of livestock slurries on land: Measurements following spreading using a micrometeorological technique and olfactometry. Journal of Agricultural Engineering Research, Vol. 48, pp. 101-110. https://doi.org/10.1016/0021-8634(91)80007-2

13. Pietrzak, S. 2006. Losses of the ammonia from manures and their environmental consequences. Nawozy $i$ Nawożenie, No. 4 , pp. 186-203. [In Polish]

14. Pote, D.H., Meisinger J.J. 2014. Effect of poultry litter application method on ammonia volatilization from a conservation tillage system. Journal of Soil and Water Conservation, Vol. 69, No. 1, pp. 17-25. https://doi.org/10.2489/jswc.69.1.17

15. Sapek, A. 1995. Emission of ammonia from agricultural production. Postępy Nauk Rolniczych, Nr 2, pp. 3-23. (in Polish)

16. Schils, R.L.M., Olesen, J.E., del Prado, A., Soussana, J.F. 2007. A review of farm level modelling approaches for mitigating greenhouse gas emissions from ruminant livestock systems. Livestock Science, Vol. 112, pp. $240-251$. https://doi.org/10.1016/j.livsci.2007.09.005

17. Strategic program of research and development "Environment, Agriculture and Forestry" - BIOSTRATEG 1, financed by the National Center for Research and Development, BIOSTRATEG 1/269056/NCBR/2015. "Interdisciplinary research on improving energy efficiency and increasing the share of renewable energy sources in the energy balance of Polish agriculture". [In Polish]

18. Talarczyk, W., Łowiński, Ł., Zbytek, Z., Nawrocki, P. 2016. A new solution for the organic fertilizer subsurface application. Selected environmental issues in modern agriculture. Vol. 9, pp. 108-113. [In Polish]

19. Webb, J., Chadwick, D., Ellis, S. 2004. Emissions of ammonia and nitrous oxide following rapid incorporation of farmyard manures stored at different densities. Nutrient Cycling in Agroecosystems, Vol. 70, pp. 67-76. https://doi.org/10.1023/B:FRES.0000045985.32440.27

20. Webb, J., Thorman, R.E., Fernanda-Aller, M., Jackson, D.R. 2014. Emission factors for ammonia and nitrous oxide emissions following immediate manure incorporation on two contrasting soil types, Atmospheric Environment, Vol. 82, pp. $280-287$. https://doi.org/10.1016/j.atmosenv.2013.10.043 